\title{
Jokes and riddles in English as a foreign language classrooms
}

\author{
Lélia Silveira Melo Souza (SOUZA, Lélia S. M.) \\ Professora Doutora na Inco-Cepel na Faculdade de Educação da Universidade de São \\ Paulo - USP \\ lsmsouza@hotmail.com
}

\section{Resumo}

Este artigo enfoca o uso de piadas como ferramenta de aprendizagem em aulas de inglês como Língua Estrangeira. O estudo foi centralizado sob seis aspectos que contribuem para uma melhor compreensão, pelos alunos, de piadas: interpretação, estrutura, ferramenta de aprendizagem, questões culturais, diferenças individuais e motivação. Ao que se refere às questões culturais, por exemplo, muitas vezes as piadas representam uma transgressão cultural, que os alunos precisariam entender para compreenderem a piada. Foram observadas as reações de alunos à apresentação de piadas em salas de aula em um Centro de Línguas da Faculdade de Educação da Universidade de São Paulo. Os resultados mostraram que o uso de piadas foi fator de motivação entre os alunos para a aprendizagem de cultura e língua estrangeira.

Palavras chave: humor, piadas, ensino/aprendizagem de língua estrangeira, pesquisa em sala de aula, cultura.

\begin{abstract}
This article focuses on the use of jokes and riddles as a tool for learning English as a foreign language and culture. The study was based on six aspects involved in helping students understand humor: interpretation, structure, learning tool, cultural issues, individual differences, and motivation. Regarding cultural aspects, for example, jokes and riddles typically portray cultural transgressions, which the students would need to perceive to be able to understand the joke or riddle. Student reactions to the presentation of jokes were observed in classrooms at the Language Center in the College of Education at the University of São Paulo. The results showed that jokes were a source of motivation for the students in learning a foreign language and culture.
\end{abstract}

Keywords: humor, jokes, riddles, foreign language teaching and learning, classroom research, culture. 


\section{Introduction}

The focus of this article is the use of humor in the classroom to help students improve their proficiency in English and, at the same time, acquire the humor competence as first put forward by Vega (1989). Research was carried out over three semesters on three different student groups, at intermediate level, in which a teacher used jokes in her classes at Inco- Cepel - the language center in the School of Education at the State University of São Paulo. ${ }^{1}$

The article includes a theoretical overview of aspects central to the use of jokes for learning purposes, followed by the presentation of jokes to students and observations on how the jokes were received.

\section{Theoretical overview}

The theoretical aspects consist of brief comments on the interpretation of jokes and the extent to which the readers/listeners are able to create their interpretations of a joke, the structure of jokes according to the theory of scripts, learning a foreign language with jokes, cultural issues concerning the use of jokes in the classroom, individual differences among learners, and differences in learner motivation.

\section{Interpretation of jokes}

According to Barzotto (2001) there are limits as to how a text can be interpreted. The reader is not totally free; he/she is bound to the way the text is structured. In the case of humorous texts, this view is relevant for "measuring" the extent to which the reader is free to interpret a joke. When encountering a joke, the reader may laugh, not like it, or not understand it. Possenti (2001) says that if a person does not understand a joke, it is due to the lack of either linguistic knowledge or knowledge of the world. This often happens with speakers of other languages. Thus, teachers need to supply this knowledge so that students can make sense of a joke. Cultures may differ in what is considered humorous and this needs to be understood by students. According to Possenti, there is just one interpretation for jokes and it has to be understood at once. If a joke has to be explained, then its comic feature disappears altogether and the text will not make sense to the hearer/listener. A lot of information is in the unsaid, but that is where the comic feature lies. "Humor is not neutral. A humorist tries for an emotional effect. Going against the pragmatic conventions of a linguistic community, i.e. stating the normally unsaid, or omitting the normally said, is the strategy most commonly used in humor" (DOLITSKY 1983, p. 47).

Take, for example, the following riddle:

What has four wheels and flies?

A garbage truck.

\footnotetext{
${ }^{1}$ This article is part of a larger study, a doctoral dissertation (O humor em aulas de língua inglesa: motivação, atitude e questões culturais, University of São Paulo), which was based on the presentation of approximately 15 jokes, to 7 groups of students, over three semesters.
} 
"Wheels" and "truck" belong to the semantic field of means of transportation, and the context leads us to interpret "flies" as insects. The reader, of necessity, has to know both meanings of "flies" in order to understand the humor.

Delia Chiaro (1992) emphasizes that if a joke is too closely linked to a specific characteristic of a country, it may not be understood in another culture. Therefore, jokes/riddles that are going to be used in a classroom setting should be selected carefully.

Furthermore, the narrator of the joke wants the reader/listener to understand the humor within a specific context. The implicit is incorporated in the discourse. Humor lies in the unsaid and on inference. According to Célia Maria Carcagnolo Gil (1991, p. 123):

As in all texts, the joke is not composed of the mere addition or juxtaposition of words and phrases at random, but it is a whole with coherence, a logical structure and a thematic development intimately related to information that has been accumulated throughout a natural language speaker's entire socialization process. $^{2}$

A joke is, therefore, not just a simple text; listeners/readers need to have background knowledge to understand it, to laugh or at least smile at it. Cook (2000, p. 150) emphasizes the need "to develop the notion of a play element in language learning in which understanding of language play may influence ideas about every aspect of teaching and learning: from the initial motivation, through the interim means, to the final goals”. Thus, language play should be part of the language learning process from the very beginning and should continue throughout the course. As a matter of fact, learning comes as a result of language play and teachers can help students to understand this play on words.

\section{The structure of jokes - theory of scripts}

The theory of scripts was the first semantic theory to explain humorous texts. It was proposed by Victor Raskin (1985, p. 81) and explained in the following manner: "The script is a large chunk of semantic information surrounding the word or evoked by it. The script is a cognitive structure internalized by the native speaker and it represents the native speaker's knowledge of a small part of the world".

In order for a text to be funny, there is an opposition of scripts. This can be illustrated in the following example:

Speaker A: My wife is an angel!

Speaker B: You're lucky! Mine is still alive.

The word "angel" triggers a different meaning thus forming the script opposition: "my wife is good versus my wife is not good". Besides the script, Raskin (1985, p. 81) proposes two other components: the trigger - the word which introduces

\footnotetext{
${ }^{2}$ My translation of the original text. "Como todo texto, a piada não é formada pela simples soma ou justaposição de palavras e frases aleatórias, mas é um todo com coerência, estruturação lógica e desenvolvimento temático intimamente relacionado às informações que se vão acumulando por todo o processo de socialização do falante de uma língua natural".
} 
the opposition - and the combinatorial rules - how the words will be connected in order to form the opposition. The author presents two hypotheses:

A text can be characterized as a single-joke-carrying text if both of the conditions are satisfied:

(i) The text is compatible, fully or in part, with two different scripts;

(ii) The two scripts with which the text is compatible are opposite in a special sense.

The following riddle exemplifies these points:

Speaker A: How can you survive in the desert?

Speaker B: By eating the sand-which is there.

In the above riddle there is opposition of the scripts "sandwich" versus "sand which”. Needless to say that the reader or listener has to perceive this opposition.

\section{Learning a foreign language with jokes}

According to Canale and Swain (1980) communicative competence entails four components: grammatical, sociolinguistic, strategic and discursive competence.

Grammatical competence - knowledge of vocabulary, rules of morphology, phonology, spelling, syntax and semantics.

Sociolinguistic competence - knowledge of social rules and usage of language. Strategic competence - verbal and non-verbal knowledge to compensate lack of linguistic knowledge.

Discursive competence - ability to interpret a text.

Vega (1989) proposes another competence: the ability to understand the script oppositions of a humorous text according to Victor Raskin (1985). However, she does not explain how students can develop this ability. A task-based language teaching approach could be used in the classroom, based on Peter Skehan's (1989) three phases. In the first one, the teacher activates the students' previous knowledge. In the second phase, it is the activity with the text itself and the development of the interlanguage. In the third phase, the teacher develops activities based on the theme of the text. ${ }^{3}$

Humor can be considered one aspect of our students' socialization process. According to Vega (1989), the humorous competence should be fostered in English as a Foreign Language classes since most individuals enjoy being surrounded by others who have a good sense of humor.

Yan Zhao (1988) emphasizes that jokes are not only for having fun, but also for helping students to learn, for example, about the habits and values of a society different from their own.

\footnotetext{
${ }^{3}$ I am using the following terminology to refer to the activities surrounding the presentation of humorous texts in the classroom: pre-reading activity, while-reading activity, after-reading activity.
} 


\section{Cultural issues}

According to Zarate (2003), the Foreign Language classroom is the place where two cultures come into contact with each other and are compared; cultural barriers may also be present due to the differences encountered by students. The cultural contact will depend on the national environment in which the foreign language is taught. For example, students learning English in Brazil have already been in contact with the English culture through songs, food, movies, etc; but they still need to discuss cultural aspects in the classroom. The description of a foreign culture may go against certain things students might consider essential, for example, the concept of "family" for Americans may differ from that of Brazilians and the teacher needs to point out the differences.

Zarate (2003) emphasizes that it is possible to present the foreign culture and, at the same time, value the national culture. However, there are many regional cultures in Brazil, in the same way that American culture is not composed of one single culture, therefore it is important to know which facet of culture will be presented in the classroom. Most of the time, the culture dealt with in the classroom is presented through a didactic book that contains stereotypes so the teacher needs to be aware of them.

Kramsch (2001, p. 51) says that culture cannot be seen as a type of ability for it is present throughout society. We are surrounded by culture and that is why it is difficult to classify it as an ability. Learning a foreign language is like being immersed in another culture that is formed of multicultural aspects. The teacher selects which part of the culture is privileged by being presented in the classroom. Thus, a person who belongs to a certain cultural group may change his/her view once in contact with a foreign culture. Therefore, we may say that he/she is going to form a third culture. According to this author, "culture puts its imprint on the conversational and narrative styles of the members of a social group. These styles are generally considered to form part of people's cultural identities”.

When studying a foreign language, one is learning a language and culture that is different from one's own. As a result, cultural barriers may initially be present in the classroom. In order to overcome these barriers, the teacher needs to take into consideration the students' previous knowledge. In the case of humor, the teacher should have sufficient knowledge about the languages and cultures involved to be able to deal with them. Since individual students do not all react in the same way to cultural aspects, each class will be different.

Humor can be seen as a transgression within its culture; consequently if the student is not familiarized with that particular culture he is not going to understand the humor in the joke. Thus, it is important for the teacher to prepare students to read/listen to the joke. Previous knowledge plays an essential role in comprehending humorous texts.

\section{Individual differences}

Individual differences that influence the understanding of jokes and riddles include, among others: cognitive styles, emotional states and personalities, and learning strategies.

Peter Skehan (1989) distinguishes learning styles that good students use. First of all, good learners are involved in their tasks. Secondly, they develop the knowledge of language as a system and make inferences. Thirdly, good students perceive language as 
a means to make inferences and interact with other people. Fourthly, good students feel more secure about what they know and their feelings towards a foreign language. Finally, they constantly review the system of the foreign language they are studying whenever certain expressions and the relationship between those expressions occur.

Teachers also need to be aware of the fact that in a classroom there may be four types of learners, according to David Nunan (1989, p. 52):

\footnotetext{
Type one: Concrete learners

These learners tend to like games, pictures, films, video, using cassettes, talking in pairs and practicing English outside the class.

Type two: Analytical learners

These learners like studying grammar, studying English books and reading newspapers, studying alone, finding their own mistakes and working on problems set by the teacher.

Type 3: Communicative learner

These students like to learn by watching, listening to native speakers, talking to friends in English and watching television in English, using English out of class in shops, trains, etc., learning new words by hearing them, and learning by conversation.

Type 4: Authoritative-oriented learners

These learners prefer the teacher to explain everything, like to have their own textbooks, to write everything in their notebooks, to study grammar, learn by reading, and learn new words by seeing them.
}

It has been my experience that only the last type of learner is not prone to like jokes in the classroom.

Peter Skehan (1989) points out that extroverted students are inclined to use more English outside the classroom and as a consequence advance more quickly in their language learning. They like having more interaction with other people. It can be said that extroverted students are more prone to tell a joke in the classroom when the opportunity arises. Moreover, students who are greater risk-takers may perform better in the classroom. Larsen-Freeman and Long (1992) say that anxiety is a component of language learning; yet it needs to be in the exact measure. If a student is too anxious, it blocks the learning process, however, a little anxiety may contribute to better learning.

Students may also differ in their learning strategies. Rod Ellis (1994, p. 531) mentions that "a strategy consists of a mental or behavioral activity related to some specific stage in the overall process of language acquisition or language use". According to O'Malley and Chamot (1990) a good learner makes connections with what he/she has previously learnt; since our knowledge is organized in blocks, they need to be linked together in order to build sound knowledge. It is possible to infer that students who can make these connections will probably understand jokes more quickly than those who cannot, as humor relies on inference.

\section{Motivation}

Motivation occurs whenever we are involved in an activity and this gives us pleasure. A motivated person tends to influence positively people are who around him/her. The learning process only takes place when a person is motivated. Ellis (1994, p. 508) points out that "language teachers readily acknowledge the importance of learners' motivation, not infrequently explaining their own sense of failure with reference to their students' lack of motivation". 
There are two types of motivation: intrinsic and extrinsic. The former is derived from students' interests, whereas the latter is constituted from external sources. Consequently, teachers need to promote students' awareness and curiosity throughout the course trying to keep the students highly motivated. Learning a foreign language means that that the individual is also going to make use of social skills and not merely learn a set of grammar rules.

Gardner (1985) and Ellis (1994) also state there are two types of motivation: integrative and instrumental. The first one occurs when the student wants to belong to a group in a culture. Humor can be a means of making this become a reality. The second occurs when students foresee advantages in learning a certain language. Ellis (1994) points out that the ideal motivation is the first one, because it is more efficient. However, in my experience of teaching English to Brazilian students I have encountered the second type of motivation more often. As teachers we need to find a way to motivate our students throughout the course. Humor can be a means to achieve that aim.

\section{Presentation of jokes and results}

This study took place at the Inco-Cepel in the School of Education at the University of São Paulo, in three English as a foreign language classes (6A, 6B and 6C), taught by the same teacher, Amparo (pseudonym). The students were observed for their reactions to the jokes presented in class. Following are the activities (pre-reading, whilereading, and after-reading) surrounding the presentation of two jokes in the classes and partial results of the observations:

Joke \# 1

\section{I - Pre-Reading Activity}

1) Do you know what blind means? Look it up in the dictionary.

2) You are going to read a joke called blind man. What are your predictions?

A)

B)

\section{II) While-Reading Activity}

Read the joke and see if your predictions were correct.

\section{The Blind Man}

A young woman has just undressed to step into the shower when the doorbell rings. She goes to the door and says, "Who is it?"

"Blind man", comes the reply.

So instead of going to the bathroom for her robe, she opens the door.

"Hummmmmmmmmm ........ nice body, lady. Where do you want the blinds?

1) What does the woman understand?

2) What does the man understand?

\section{III) After-Reading Activity}

This joke is about a misunderstanding. The man means one thing and the woman understands another. Tell your friend about a misunderstanding that happened in your life. 
Amparo asked the students to check for the two meanings of blind: cego versus persiana. The students, working in groups and using their dictionaries checked the meanings accordingly. The 6C students came up with the following predictions.

\section{Predictions}

1. It's a story of a man who wakes up at night and can't see.

2. It's a story about a blind man at the bus stop chewing gum.

3. It's a story about a salesman who sells blinds.

The second prediction was made by a 6C student, Euclides (all student names in this article are pseudonyms), based on a short story by the famous Brazilian writer Clarice Lispector. Amparo immediately recognized the similarity. The students read the joke and most of them understood it and laughed a lot. In all the groups, Amparo read the joke aloud and explained the humor in it: homem cego versus homem das persianas. All of a sudden, the unsaid was revealed and the teacher needed to explain the joke.

According to Dolistky (1983) the explanation of a joke would ruin the humorous effect, but this did not happen. The students were eager to listen to the teacher's explanation of the joke and those who had not understood the joke immediately joined in the laughter with the rest of the class. A cultural barrier occurred in group 6B when one student said it was impossible for this to happen: the lady in the joke would not misunderstand homem das persianas versus homem cego.

Joke \# 2

\section{Pre-Reading Activity}

Ask this question to a friend in class. Don't read the joke yet!

1) When you were a child, did you think your parents were the best in the world? Why? Why not?

\section{While-Reading Activity}

1) Read the joke and see how the boys feel about their parents.

\section{My father is the greatest}

Three boys are in the schoolyard bragging (1) of how great their fathers are. The first one says:

"Well my father runs the fastest. He can fire an arrow (2), and start to run, I tell you, he gets there before the arrow."

The second one says:

"Ha! You think that's fast! My father is a hunter (3). He can shoot his gun and be there before the bullet (4)

"The third one listens to the two and shakes his head. He then says:

"You know nothing about fast. My father is a civil servant (5) He stops work at 4.30 and he's home by 3.45 !

2) Read the joke again and try to guess the meaning of the words in italics

1.

2.

3. 
4.

5 .

\section{After-Reading Activity}

1) Discuss the questions below

Can you think of any professions about which people make jokes?

Are they funny? Do you like them?

In the above joke, students learned about the stereotype of a person who works as a civil servant.

This background cultural knowledge is also shared by Brazilian students thereby making the joke easily understood. There is the following opposition in the scripts: hard worker versus lazy. Amparo also read the joke aloud and explained it. The students mentioned several professions about which it is common to make jokes: lawyers, architects, engineers, clowns, teachers, salesmen, nurses, football players, doctors and priests.

The class 6B laughed at the joke about the civil servant and apparently enjoyed it. Yet, in another class, 6A, Laurinda and Rocilda OK said they never understood the jokes. We presume that they may not have understood the jokes because of a cultural barrier, i.e. an inability to understand the implicit in the text, or maybe because someone in their families was a civil servant.

In group 6C José mentioned that he loved jokes, even though he was always the last one to get the joke or sometimes did not understand them at all. We assume that what the student liked was the atmosphere of laughter and enjoyment that spread throughout the class once the teacher announced that it was joke time. In this class, Amparo asked the students if anybody knew a joke about a profession - it could even be told in Portuguese. Oswaldo immediately volunteered and told the following joke:

Oswaldo - "I'll try to tell a joke in English. There was an engineer who went to Heaven and God asked him to build some things. So the engineer started building a lot of things in Heaven. Then the devil asked God if he could borrow the engineer to build things in Hell. So the engineer built many things in hell. A long time passed and the engineer was still in Hell. God got irritated and said "I’ll sue you". The devil answered: "I wonder if you have lawyers in Heaven".

These are examples of how students may feel and react once they are exposed to humor in the form of jokes. They offer the opportunity to interact with other students, may provide extra motivation and are another means to learn a language.

\section{Final remarks}

Based on the above examples of jokes and activities presented in the classroom and the reaction of the students, it can be concluded that jokes may increase motivation for learning and rapport among students in the classroom. The manner in which the activities surrounding the jokes were set up (pre-reading, while reading and after reading), may have contributed to students feeling they are learning and having fun at the same time. One student even volunteered to tell a joke in English. Cultural aspects were discussed and students learnt how to deal with them. They discovered similarities between Brazil and the United States in the form of stereotypes. Thus, humor and 
learning come together in this type of activity, which helps students enjoy the classes more.

Dolitsky (1983) emphasized that humor relies on the unsaid, but when used in the classroom for didactic purposes, it was found that most of the time the unsaid had to be revealed; otherwise some students would not understand the comic effect. After the teacher explained the humor, the students laughed and were happy to participate with other students in enjoying the atmosphere of the class.

The jokes used in this study were successful in the classes observed. Teachers need to be careful to select jokes that their students will understand, and then prepare appropriate activities or exercises. After all, students need to feel they are learning with the jokes as well as with any other text used in the classroom. Laughter in the classroom tends to promote a good atmosphere and a desire to learn more.

\section{References}

BARZOTTO, Valdir. Olhares oblíquos sobre sentidos não muito dissimulados. In: GREGOLIN, Maria do Rosário; BARONAS, Roberno (Orgs.). Análise do discurso: as materialidades do sentido. São Carlos, São Paulo: Claraluz, 2001. p. 205-217.

CANALE, Michael; SWAIN, Merril. Theoretical bases of communicative approaches to second language teaching and testing. Journal of Applied Linguistics. v. 1, p 1-47, 1980.

CHIARIO, Delia. The language of jokes: analyzing verbal play. London and New York: Routledge, Interface Series, 1996.

COOK, Guy. Language play, language learning. Oxford: Oxford University Press, 2000.

DOLITSKY, Marlene. Humor and the unsaid. Journal of Pragmatics, p. 39-48, 1983.

ELLIS, Rod. The study of second language acquisition. Oxford: Oxford University Press, 1994.

FREEMAN-LARSEN, Diane; LONG, Michael Herbert. An introduction to second language acquisition research. London; New York: Longman, 1992.

GARDNER, Robert. Social psychology and second language learning. London: Edward Arnold, 1985.

GIL, Célia Maria Carcagnolo. A linguagem da surpresa. 1991. Tese (Doutorado) Universidade de São Paulo, São Paulo, 1991.

KRAMSCH, Claire. Context and culture in language teaching. Oxford: Oxford University Press, 2001.

NUNAN, David. Understanding language classrooms. New York: Prentice Hall, 1989. 
O’MALLEY, J. Michael; CHAMOT, Anna U. Learning strategies in second language acquisition. Cambridge; New York; Melbourne: Cambridge University Press, 1990.

POSSENTI, Sírio. Os humores na língua. Campinas: Mercado de Letras, 2001.

RASKIN, Victor. Semantic mechanisms of humor. Boston, Lancaster: De Reidel Publishing Company, 1985.

SKEHAN, Peter. A cognitive approach to language learning. Oxford: Oxford University Press, 1989.

SOUZA, Lélia. O humor em aulas de língua inglesa: motivação, atitude e questões culturais. 1997. Tese (Doutorado) - Universidade de São Paulo: São Paulo, 1997.

VEGA, Gladys Martha. Humor competence: the fifth component. 1989. Thesis (Master of Arts) - Purdue University, Purdue, Indiana, 1989.

ZARATE, Genevière. Representatons de l'etranger et didactique dês langues. Essais collection Credif dirigée par Françoise Lapeyre, Didier, Paris, 2003.

ZHAO, Yan. The information-conveying aspect of jokes. International Journal of Humor Research. v. 1-3, p. 279-298, 1988. 